\title{
A Study of how Kate is Portrayed as a Shrew in The Taming of the Shrew by Shakespeare
}

\author{
Ling Yu \\ Chengdu University, Chengdu 610000, Sichuan Province, China
}

Author Information: Ling Yu (1986.7.12), male, Han nationality, Chengdu local, Sichuan Province, Assistant Lecturer, Master ( $\mathrm{PhD}$ in progress). Main research focus: second language acquisition and English language teaching.

\begin{abstract}
Katherine, also called Kate, is the shrew in the play The taming of the shrew, one of Shakespeare's earliest comedies. She first appears in the play as a young woman who insists on saying whatever she thinks and expressing freely whatever she feels. Her words are regularly abusive and angry, and her actions are often violent. More seriously, she is not respectful or obedient towards her father Baptista, who she thinks favors her younger sister, Bianca. In contrast to Kate, she appears to be sweet, soft-spoken and obedient, an image of a good girl. Furthermore, no sooner does Kate meet her sole suitor, Petruchio, than they engage in a battle of wordplay and threaten each other's face. Owing to these "unruly" behaviors, Kate inescapably establishes a reputation of a shrew in a patriarchal society, where women are expected to be obedient to man. Living in a patriarchal society, Kate is talkative and disobedient to the males who are supposed to have authority over her. This leads to her being labeled as a shrew, as women in that period were expected to be silent and obedient. Kate's shrewish disposition is revealed in the way in which she talks to her male counterparts such as suitors of Bianca, her father, and her sole suitor, who later becomes her husband. That is, although Kate is violent and not respectful to people around her, it is the talkativeness that makes Kate a shrew, as it clearly posts the greatest challenge to the male supremacy.
\end{abstract}

Key words: Katherine; Kate; The Taming of the Shrew

Publication date: April, 2021; Publication online: 30 April, 2021

*Corresponding author: Ling Yu, yuyanzhecdu@163.com

\section{Introduction}

Katherine, also called Kate, is the shrew in the play The taming of the shrew, one of Shakespeare's earliest comedies. She first appears in the play as a young woman who insists on saying whatever she thinks and expressing freely whatever she feels. Her words are regularly abusive and angry, and her actions are often violent. More seriously, she is not respectful or obedient towards her father Baptista, who she thinks favors her younger sister, Bianca. In contrast to Kate, she appears to be sweet, soft-spoken and obedient, an image of a good girl. Furthermore, no sooner does Kate meet her sole suitor, Petruchio, than they engage in a battle of wordplay and threaten each other's face. Owing to these "unruly" behaviors, Kate inescapably establishes a reputation of a shrew in a patriarchal society, where women are expected to be obedient to man.

There was a rigid gender hierarchy in the English society in Shakespeare's time. A daughter was expected to be submissive towards her father; a wife owes obedience to her husband. In short, women were expected to be obedient, chaste and silent. As a result, those who dare to express their ideas or demand independence are seen as unruly women or shrews. Kate is, of course, a dramatized character by Shakespeare, and as such she talks excessively and behaves violently to an absurd degree. The current study is aimed to investigate how Shakespeare portrays Kate as a shrew, particularly through the following aspects: (1) Kate's verbal aggressiveness towards Baptista; (2) her disobedience and resistance to Petruchio; (3) her violent behaviour towards Bianca; (4) the comparison between "shrewish Kate" and "sweet" Bianca ; (5) the comments of her male counterparts about her. Finally, it is suggested that Kate's sharp tongue is the largest contributor to her reputation of a shrew, 
compared to other kinds of "disobedient" behaviour.

\section{Summary of the Play}

Baptista, a local nobleman in Padua, insists that no one be allowed to court his younger daughter, Bianca, until the elder daughter Catherine first weds. According to the remarks of Gremio and Hortensio, both of whom are Bianca's suitors, there seems little likelihood of Kate marrying anyone. In contrast to Kate, Bianca appears to be sweet, silent and obedient, which makes Lucentio, a young nobleman from Florence, fall hopelessly in love with her. Lucentio then endeavors to gain access to Bianca, disguising himself as a Latin tutor for her in order to court her secretly. Meantime, Hortensio disguises himself as a music tutor for Bianca, with the same purpose as Lucentio. However, as Lucentio is expected to be in Padua, he commands his servant Tranio to assume his role.

The second act opens with Kate binding and threatening Bianca. Shortly Baptista enters and separates the fighting sisters. As the girl leaves, the group of suitors arrive. All of Bianca's suitors bring gifts to Baptista, and Petruchio announces his attention to court Kate. Baptista accepts the two tutors and then confers with Petruchio about Kate's dowry, on the premise of his wooing her successfully.

At Petruchio and Kate's first meeting, they attack and threaten the face each other by insults and slurs. Although Kate clearly denies Petruchio's advances, he remains undaunted and insists that they will be married very soon. Moreover, Petruchio lies to his peers that Kate is obedient in private but intentionally appears to be willful in public, and quickly announces their wedding. Then the focus of Baptista shifts from Kate to Bianca. He announces whoever can offer a dower worth the most will be the groom of Bianca. Finally, Tranio (disguised as Lucentio) wins on the premise that he can prove the property he claims to have. In the meantime, Lucentio and Hortensio begin to instruct Bianca, with attempts to win her heart. She is clearly more receptive to Lucentio's advances than she is to Hortensio's. Hortensio soon realizes that Bianca probably favors his rival, and turns to a rich widow instead.

Kate's wedding day approaches but Petruchio does not show up in time. This makes Kate disappointed and desperate. Petruchio finally arrives, although dressed inappropriately. He perhaps here attempts to mirror the absurd behavior of Kate. After the wedding ceremony, during which he scolds and even strikes the priest, Petruchio insists on heading back to his country house immediately, with Kate. Upon arriving at Petruchio's house, Kate is denied food and sleep, all under the guise of love to her. Later Petruchio claims that they will return to Padua. When Kate corrects the time by which they will reach to Padua, Petruchio threatens to call the trip off until Kate agrees whatever he says. Kate finally gives in and obeys whatever Petruchio says, claiming the sun as the moon and an old man as a young woman. This leaves Hortensio, who has met with them, marveling at the changes to Kate he has just witnessed.

The play ends with a banquet at which the men wager over whose wife is the most obedient. Bianca, Lucentio's wife, is, of course, expected to be the most submissive wife, and Kate the most disobedient one. However, when Lucentio calls for Bianca, she refuses to obey. When Hortensio next beckons the widow, she commands him to come over to her. Finally, it is Petruchio's turn to call for his wife. Much to everyone's surprise, when Petruchio orders Kate to come, she comes straightaway. Obeying Petruchio's instruction, she gives a long speech concerning the obedience a woman owes her husband. Kate's speech draws the curtain of the play. It leaves the guests astounded at the her transformation, while Kate and Petruchio leave the party together to "consummate" their marriage.

\section{Women's speech in Shakespeare's time}

English society in Shakespeare's time was strongly patriarchal: there was a rigid gender hierarchy, with women regarded as inferior to men (Smith, 2013: 3). A Wife had few property rights but owed great obedience to her husband. Women of a marring age were generally expected to marry and produce heirs. However, it seemed unlikely that a talkative women would easily win a husband, as speech was considered primarily masculine or appropriate to males (Van Note, 2010).

"Silence in a Woman is a mouing Rhetorical, winning most, when in words it wooeth least" (Richard Brathwait, 2008; cited in Van Note, 2010: 16). At that time, conduct literature concerning women's behavior laid much emphasis on wifely silence, chastity and obedience. Wife who could control her speech was perceived as submissive to her husband. Moreover, popular woks by Tilney and others (2005), for example, speak highly of the wife's silence as showing deference to her husband. William 
Whately (2009) argues even further that women who are naturally inclined to produce aggressive, abusive speech must be wary of their speech and gestures, showing reverence to their husband.

Eloquence was considered a positive characteristic in males only: an eloquent woman was likely to be labeled as a shrew. Women's verbal eloquence was demonized and frequently subject to punishment, either informal or legal. This is because men took women's speech as a potential threat to their personal agency, for instance, to the property they owned (Van Note,2010:17). As the historian Anthony Fletcher (1995) notes, “Women's talk always threatens disorder; women's silence thus comes to be prized to an absurd degree".

A silent women was thus believed to be an ideal wife in that silence was generally taken as the synonym for obedience. The ideal wife was thus deprived of the learned language, lest they would develop rhetorical skills. Silence then became the only acceptable way women fashioned themselves in public (Van Note 2010: 99).

The silence frequently referred to in conduct literature is, however, a relative silence rather than an absolute lack of speech (Van Note, 2010; 118). Excessive talkativeness and absolute silence were both viewed as negative by scholars, for instance, Gouge (2008) further argues that feminine silence is as "a subjective rather than a subjected space". That is, silence not only indicated obedience but also demonstrated a sort of resistance. There could be women who appeared to be silent and obedient, with an attempt to reach a certain goal. Silence then could be interpreted as a strategy, akin to the intractability of shrewishness (Van Note, 2010).

The word "shrew" was earlier applied to men who were overly talkative, violent and aggressive (Smith, 2013: 6). However, in Shakespeare's time, this term referred particularly to verbal-aggressive and disobedient women, especially wives (Smith, 2013: 6). A shrewish wife not only tended not to submit to her husband but also demanded independence. These behaviors threatened the husband's dominance within the household and challenged the male authority. Such shrewish behaviors would lead to public punishment, such as 'rough-music' and a mock beating, varying among women of different social rank. Not only were these practices of punishment designed to shame the shrewish wife, but also humiliated the husband who is incapable of controlling his wife (Van Note, 2010: 112).
The excessive emphasis laid on women's speech and disobedience reveal the fears and anxieties of the male concerning the changes in the gender hierarchy. Hence, talkative women were portrayed as the shrew, who threatened the masculine power in terms of speech and thus became unreadable in a male-dominated, patriarchal society (Van Note, 2010: 128).

In Shakespeare's comedy the Taming of the Shrew, the heroine Kate meets in every sense the criterion of being a shrew, who talks excessively. In what follows, a detailed analysis of Kate's shrewishness will be carried out.

\section{The Portrayal of Kate as a Shrew}

\subsection{Kate's Shrewish Behaviors}

To begin with, Kate scolds and even strikes her sister Bianca. In the first scene, she mocks at Bianca's conscious obedience, addressing her as "a pretty peat" (1.1.78). Act two opens with Kate binding and questioning Bianca: "whom thou lov'st best/ See thou dissemble not". Frightened by Kate, Bianca is willing to help her woo whoever she likes (2.1.15). Surprisingly, Kate is not appreciative of Bianca's generosity, but rather strikes her. This may be attributed to Bianca's words - "is it for him you do envy me so?", which perhaps are too accurate to be appreciated. In contrast to Bianca, who has a abundance of suitors and is the favored daughter, Kate was unlikely to win a husband and then would have to "dance barefoot on her wedding day" (2.1.33). Therefore, although Kate is violent towards Bianca, which partly makes her a shrew, her violent behaviors may not be unprovoked, perhaps out of fear and envy.

Furthermore, Kate is unsubmissive and verbally aggressive towards her father Baptista. In Shakespeare's time, a daughter was supposed to be utterly obedient to her father. Violating this convention, Kate earns herself a reputation as a shrew. When Baptista, in the first act, suggests that Kate might stay with the suitors of Bianca, Kate argues willfully, indicating her unruliness:

Why, and I trust I may go too, may I not?

What, shall I be appointed hours, as though, belike,

I knew not what to take and what to leave? Ha! (1.1.102104).

In addition, when Baptista comes over to placate the fighting sisters and rescues Bianca (in Act1, Scene2), Kate scolds him:

What, will you not suffer me? Nay, now I see She is your treasure, she must have a husband I must dance barefoot on her 
weeding day And, for your love to her, lead apes in hell.

Talk not to me, I will go sit and weep

Till i can find occasion of revenge. (2.1.31-35)

It is hard to imagine that any girl in a patriarchal society could speak to her father in such a way. Not only does Kate scold Baptista for his bias towards Bianca, she also threatens to revenge that. This behaviour against her father definitely enhance her characterization as a shrew in the play. In addition, Kate appears to be violent and talkative when she first meets her sole suitor, Petruccio. Petruccio has already heard of Kate's notorious disposition before their initial meeting, so devises a oppositional strategy against Kate, for example:

Say that she rail, why then I'll tell her plain

She sings as sweetly as a nightingale. (2.1.169-170).

Upon meeting Kate, they immediately engage in a battle of wordplay, involving a variety of rhetorical devices by which they threaten each other's face and posit verbal challenge as well. For example, when Kate attacks by scolding: "I knew you at the first/ You were a movable (2.2.195-196/ A joint-stool(2.2.198)", Petruccio counterattacks smartly - "Thou has hit it: come, sit on me" (2.1.199). Even though Petruccio speaks highly of Kate's virtue and disposition, such as "mildness" and "the virtues spoke of", Kate rejects his compliment, claiming she is "too light" or "too heavy" for Petruccio to catch (2.1.205-206). In the verbal battle, Kate shows off rhetoric facilities: "A movable" referring to Petruccio being changeable and "a joint stool" to men who are easily overlooked (Hodgdon, 2010). When Petruccio announces their wedding on Sunday, she swears: "I'll see thee hanged on Sunday first" (2.1.3002). In Shakespeare's time, the rhetoric facility was considered masculine agency, which was meant to be inaccessible to women. More importantly, women were not expected to verbally attack men in a patriarchal society.

Predictably, the marriage itself fails to change Kate, who is still the shrew after she gets married. This can bebest illustrated when Petruccio orders Kate to leave her wedding feast back to his country house, Kate retorts:

Do what thou canst, I will not go

today, No, nor tomorrow-not till I

please myself. The door is open, sir,

there you're your way.

Consequently, she is carried away onto a horse heading back to Petruccio's. She fought with Petruccio along the way. Upon arriving at Petruccio's house, Kate is denied food, sleep and clothing adornment, all under the pretense of Petruccio taking especial care of her. Eventually she fails to refrain from the fury, scolding at Petruccio:

You betters have endured me say my mind, And if you cannot, best you stop at your ears.

My tongue will tell the anger of my heart. (4.3.75-78).

Kate, as a wife, in a patriarchal society, scolding her husband certainly violates the convention that the wife should be silent and submissive to her husband. Furthermore, she even corrects Petruccio, though righty, when he intentionally announces the wrong time by which they will get to Baptista's house(4.3.188-189). In order to secure his supremacy, Petruccio retorts that "It shall be what o'clock I say it is" (4.3.194). In this play, Petruccio demands absolute obedience from his wife and thus deliberately behaves violently and absurdly. He may carry the expectation of obedience to extremes, whereas the submissiveness in reality is found somewhere between the absolute silence and extreme talkativeness. Unsurprisingly, Kate, as any average wife would do, argues with and correct him.4.2 Bianca's Silence and Obedience

Bianca, whose image of an ideal girl seems to be at Kate's expense, is seemingly silent and obedient.. Bianca's silence makes Lucentio to describe her as having "Maid's mild behaviour and sobriety" (1.1.71). It is undeniable that Bianca in this whole play indeed speaks deferentially to Kate and Baptista. Even though Kate aggressively addresses her as "a pretty peat" (1.1.78), Bianca does not retort with harsh words but respectfully addresses Kate as "sister". Furthermore, she indeed does not speak any bitter word to Kate, even though the latter strikes her. In contrast to Kate, who rants and raves at Baptista, Bianca is submissive to her father and addresses him respectfully: "Sir, to your pleasure humbly I subscribe" (1.1.81). A comparison will be inevitably made between the sisters in terms of their dispositions. Therefore, through providing a contrast, Bianca's silence and obedience to some degree help create the image of Kate as the shrew.

\subsection{Kate's reputation of a shrew}

Apart from the direct demonstration of Kate's shrewish disposition through her speech and actions, the comments of her male counterparts also contribute much to her portrayal as a shrew in the play. In fact, Kate speaks 
deferentially in the beginning of the play to both her father and Bianca's suitors, where she addresses them "sir". Kate does not verbally attack these suitors until they claim Kate is not "of gentler" or "milder mould" (1.1.60). Due to her harsh words, as she claims to paint their face and use them like a fool, Hortensio and Gremio take Kate as a devil. Moreover, even the spectator Tranio describes Kate as "stark mad or wonderful forward" (1.1.69). More important, before meeting Kate, Petruccio has already known, from the men who know Kate, that she is "an irksome brawling scold"(1.2.186). This would inevitably give him a preconception before the initial meeting with Kate. Talkativeness contributes more than other violent behaviour to Kate's reputation as a shrew. This is because women's speech is in Shakespeare's time viewed as a clear threat to male agency (Van Note, 2010: 116). According to Fletcher, cited in Van Note (2010: 116), “men's control of women's speech, an aspect of their potency, was at the heart of the early modern gender system". Speech at that time was primarily regarded as a masculine trait and thus women are expected to be silent, particularly in public. Besides, a women's tongue was perceived as the counterpart of a man's penis, thus her eloquence was inevitably related to sexuality (Jardine, cited in Van Note 2010: 117). Consequently, women's speech was demonized as threats to the male agency as their infidelity. In this play, Kate is best characterized by the way she talks, as she scolds her sister; raves and rants at her father; engages in the wordplay with her sole suitor-Petruccio. This would inescapably lead Kate's male counterparts to take her as a shrew.

\section{Conclusion}

Living in a patriarchal society, Kate is talkative and disobedient to the males who are supposed to have authority over her. This leads to her being labeled as a shrew, as women in that period were expected to be silent and obedient. Kate's shrewish disposition is revealed in the way in which she talks to her male counterparts such as suitors of Bianca, her father, and her sole suitor, who later becomes her husband. That is, although Kate is violent and not respectful to people around her, it is the talkativeness that makes Kate a shrew, as it clearly posts the greatest challenge to the male supremacy.

\section{References}

[1] Fletcher, Anthony. Gender, Sex and Subordination in England 1500-1800. New Haven: Yale UP, 1995. Print.

[2] Hodgdon, B. (ed.). 2010. The Taming of the Shrew. London: Methuen Drama/Bloomsbury Publishing.

[3] Gouge, W. Of Domesticall Duties: Eight Treatises. London, 1622. Early English Books Online. Web. 14 Aug. 2008.

[4] Mazzio, C. 1996. 'Sins of the Tongue in Early Modern England'. Modern Language Studies, 28: 93-124.

[5] McAlindon, T. 1973. Shakespeare and Decorum. New York: Harper \& Row Publishers, ING. Tilney, E. A briefe and pleasant discourse of duties in Mariage, called the Flower of Friendshippe. London, 1568. Early English Books Online. Web. 4 Nov. 2005.

[6] Van-Note, B. 2010. Performing Women's Speech in Early Modern Drama: Troubling Silence, Complicating Voice. Texas: Texas A\&M University.

[7] Whately, W. A Bride-Bvsh, Or, a Direction for Married Persons. London, 1619. Early English Books Online. Web. 21 May 2009. 